\title{
Testate Amoebae as Paleoclimatic Proxies In Rocky Mountain Peatlands: A CASE Study IN THE GREATER YELLOWSTONE ECOSYSTEM.
}

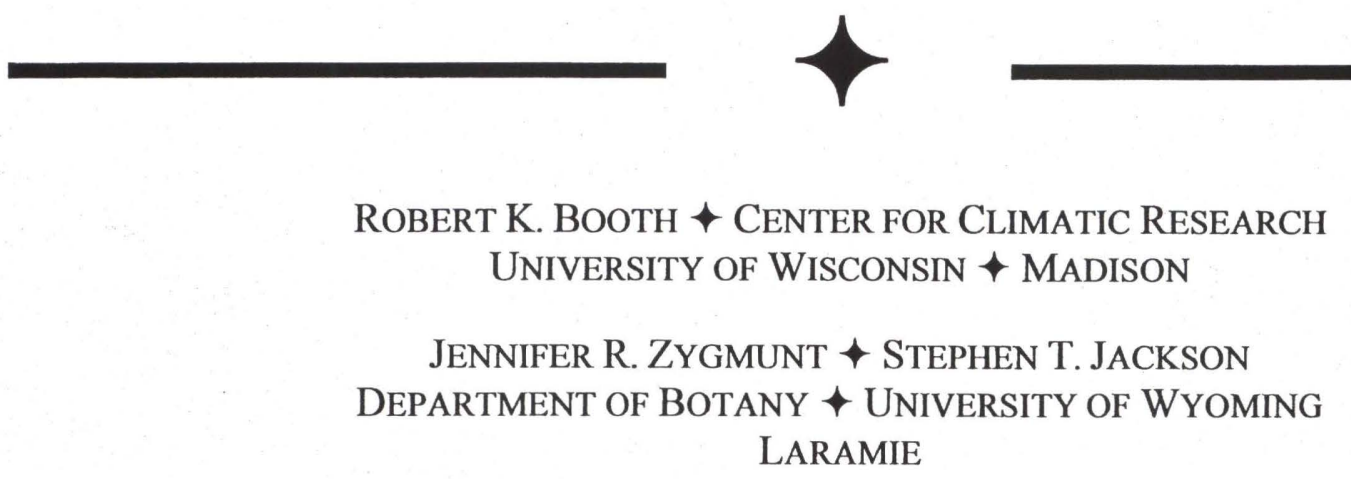

\section{$\downarrow \quad$ AbSTRACT}

We investigated the potential of testate amoebae (Protozoa:Rhizopoda) for reconstructing past climate changes in the Rocky Mountain region. Our specific objectives were to determine environmental controls on modern testate amoeba distribution in Sphagnum-dominated peatlands of the region, reconstruct past temporal changes in testate amoebae from a Sphagnum-dominated peatland in southwestern Yellowstone National Park, and assess relationships between climate variability and testate amoebae for the past century. Our results indicate that substrate moisture is the dominant control on modern testate amoeba distribution in the region, consistent with studies from other regions. Temporal changes in testate amoebae reconstructed from a floating peat mat in the Greater Yellowstone Ecosystem show considerable variability during the past several hundred years, and variability during the past century was correlated with the instrumental record of drought at decadal timescales. The patterns suggest that sensitive paleoclimatic reconstructions are possible from floating mats in the region, and perhaps elsewhere. Testate amoebae from peatlands in the Rocky Mountains show great potential for reconstructing past climate variability, corroborating and extending records inferred from other proxies.

\section{$\downarrow \quad$ INTRODUCTION}

Peatlands are valuable archives of past environmental and climatic variability (e.g. Barber, 1993; Blackford, 2000; Charman, 2002). Continuous records of paleoclimate spanning the mid to late Holocene with multidecadal to centennial-scale temporal resolution have been obtained from peat stratigraphy in various regions of the world, including Europe (e.g., Chambers et al., 1997; Barber et al., 2000, 2003; Hughes et al. 2000; Charman and Hendon, 2000; Langdon et al., 2003), New Zealand (Wilmhurst et al., 2003), and the Great Lakes region of North America (Booth and Jackson, 2003; Booth et al., 2004). These studies typically involve the reconstruction of temporal changes in peatland hydrology, which is controlled by precipitation, evaporation, and temperature (Barber et al., 2000; Charman et al., 2004; Hendon and Charman, 2004). Investigations have focused on Sphagnum-dominated peatlands, and in particular, ombrotrophic peatlands such as raised and blanket bogs. Ombrotrophic peatlands derive all moisture from atmospheric sources and contain particularly sensitive records of past climate (Blackford, 1993; Charman, 2002). However, other Sphagnum-dominated peatlands have also been shown to contain sensitive records of past climate variability (Anderson, 1998; Hendon et al., 2001; Booth et al., 2004). 
Temporal changes in past surface-moisture conditions can be reconstructed from peat stratigraphy using a variety of proxies (Blackford, 1993; Charman, 2002). Testate amoebae, a group of amoeboid protozoans that produce a decay-resistant outer shell, are particularly useful proxies within Sphagnum-dominated peatlands, where their distribution is primarily controlled by substrate moisture (Charman, 2001). Relationships between species composition and hydrology have been quantitatively modeled (e.g., Charman and Warner, 1992, 1997; Charman, 1997; Woodland et al., 1998; Mitchell et al., 1999; Booth, 2001, 2002; Wilmhurst et al., 2003). Various modeling techniques have been used to describe relationships between species composition and substrate moisture, particularly water-table depth, and these relationships have been used to reconstruct past moisture fluctuations from subfossil assemblages (Warner and Charman, 1994; Woodland et al., 1998; Hendon et al., 2001; Booth and Jackson, 2003). In North America, paleohydrological applications of testate amoebae have been explored in Sphagnum-dominated peatlands of the Great Lakes region (Warner and Charman, 1994; Booth 2001, 2002; Booth and Jackson, 2003; Booth et al., 2004) but modern calibration datasets are needed from other regions and peatland types.

Sphagnum-dominated peatlands are scarce in the Rocky Mountain region, and truly ombrotrophic peatlands are absent (Windell et al., 1986). However, Sphagnum-dominated peatlands do occur in isolated topographic and hydrological settings, particularly as floating peat mats on oligotrophic lakes and in areas of relatively acidic groundwater discharge (e.g., 'iron fens'). In this study, we investigated the potential of testate amoebae for reconstructing past environmental and climatic variability in peatlands of the Greater Yellowstone Ecosystem, and elsewhere in the Rocky Mountains. Our primary objectives were to identify environmental controls on testate amoebae within Sphagnum-dominated peatlands of the region, and to investigate past temporal changes in the relative abundance of testate amoebae from the sediments of a floating peatland. To assess whether testate amoebae preserved in the sediments of a floating peatland can be used to reconstruct past climate variability, we compare temporal changes in testate amoebae with instrumental climate data for the past century.

\section{STUDY SITES}

To locate Sphagnum-dominated peatlands in the Rocky Mountain region, data on the distribution of known peatlands and obligate peatland vascular plant species were obtained from the Wyoming Natural Diversity Database, the Rocky Mountain Herbarium, and the Colorado Natural Heritage Program, and compiled with information on the known distribution of Sphagnum in Wyoming and Colorado (R.E. Andrus, unpublished data). Fifteen Sphagnum-dominated peatlands within Wyoming and Colorado were identified (Figure 1). Five of these peatlands were "iron fens," which are characterized by highly acidic groundwater ( $\mathrm{pH} 3.3-3.4)$ that is rich in dissolved iron and sulfur (Carsey et al., 1999). The acidic environment in these peatlands supports relatively unique plant communities dominated by Sphagnum and other mosses (Carsey et al., 1999). Except for two small peatlands in central Colorado (Henderson A and B), the other peatlands we sampled were floating mats adjacent to or within small lakes (Table 1). There was considerable environmental variation within and between peatlands (Table 1).

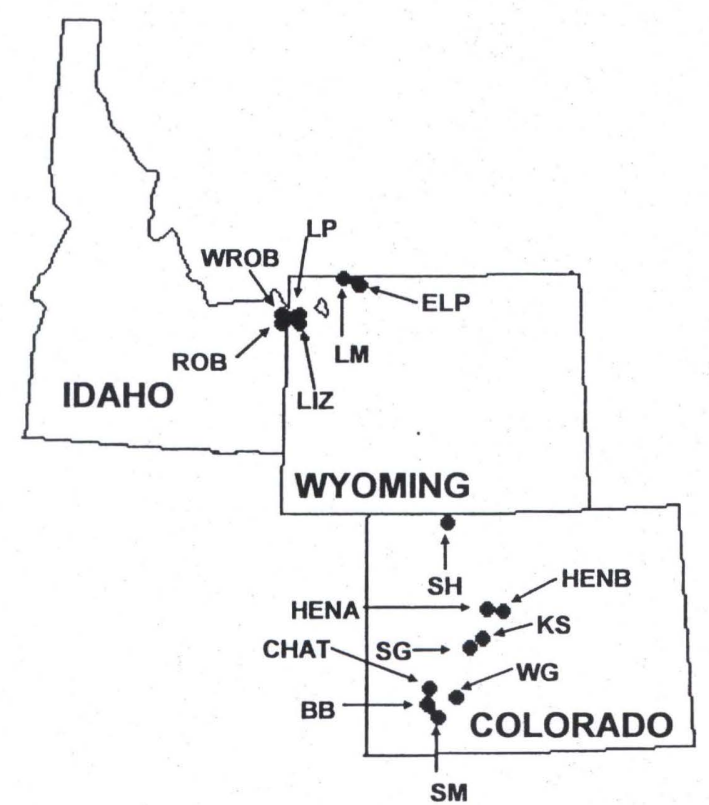

Figure 1. Location of peatlands sampled in the central and southem Rocky Mountains. Peatland abbreviations, and characteristics of each site, are listed in Table 1. 


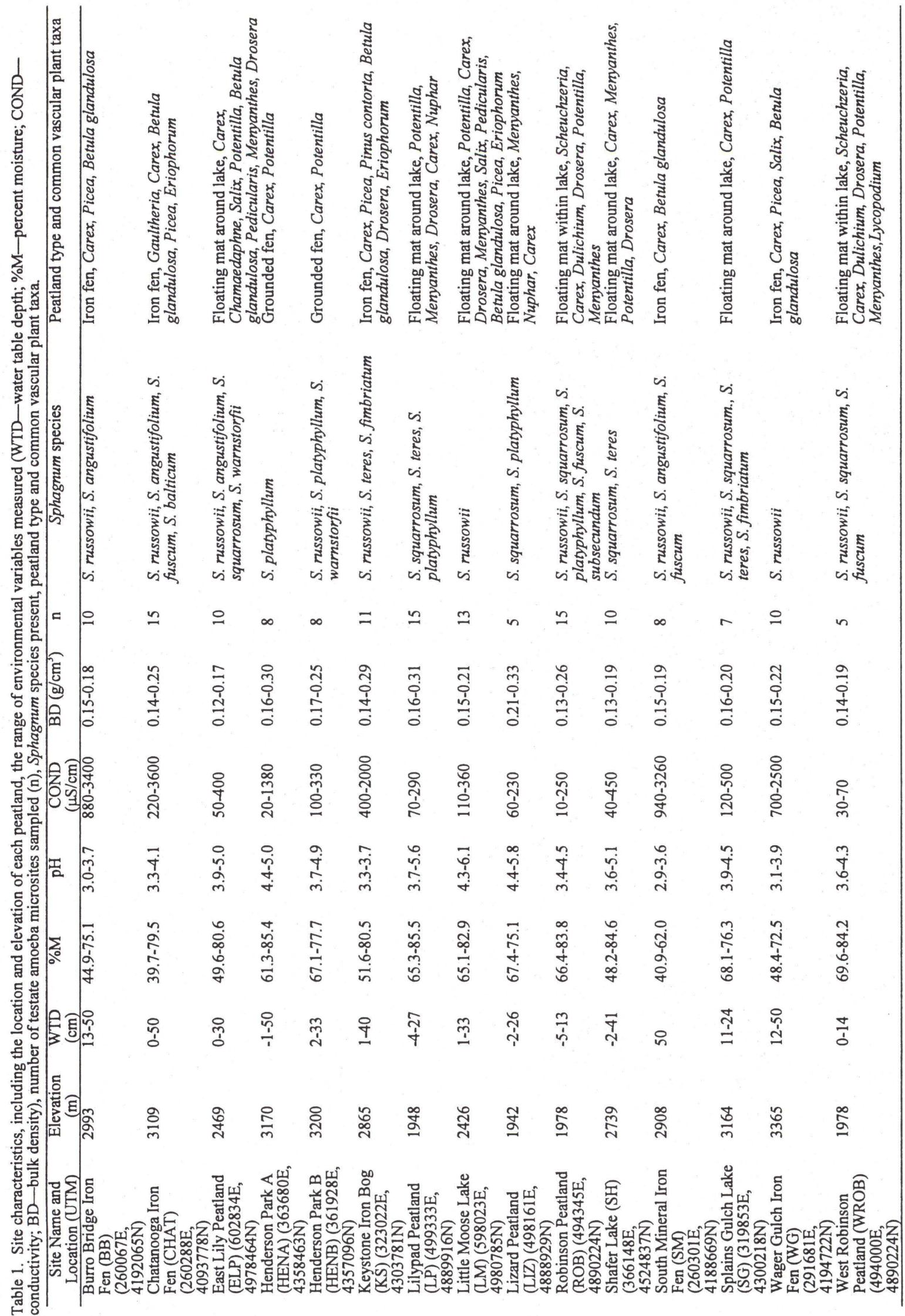


A sediment core was collected from Robinson Peatland, a floating peat mat in the center of a lake basin in southwestern Yellowstone National Park, in June 2002. Dominant vegetation on the floating mat included Sphagnum, Scheuchzeria, Carex, Dulichium, Drosera, Potentilla, and Menyanthes. Open water surrounding the mat was dominated by Nuphar, and the surrounding forest was dominated by Pinus contorta.

\section{$\uparrow \quad$ METHODS}

\section{Modern calibration dataset}

Modern testate amoeba assemblages were collected during June and July of 2002. Collection procedures generally followed previous studies (e.g. Woodland et al., 1998; Mitchell et al., 1999; Booth, 2001, 2002). In each peatland, 5-15 testate amoeba samples were collected in an attempt to represent hydrologic (i.e. wet and dry sites) and biotic (i.e. areas of different vegetation) variability, although we focused on sites where Sphagnum was present. At each sampling site, a peat sample was taken by pushing a metal can (11 cm long, $7.5 \mathrm{~cm}$ in diameter) with one open end (and a hole in the other end to allow air to escape) into the peat until the top of the can was level with the vegetative surface (about $11 \mathrm{~cm}$ deep). This peat sample was sealed and returned to the lab for calculation of bulk density and percent moisture. Modern testate amoeba assemblages were collected by taking approximately $10 \mathrm{~cm}^{3}$ of brown Sphagnum (found directly below the green part of the stem, typically 3-6 cm deep) from the edge of the hole left from the peat sample. The brown part of the stem is thought to contain amoebae that are most representative of those found in the fossil record (Warner, 1987), and also contains higher diversity than upper portions of the stem (Booth, 2002; Mitchell and Gilbert, 2004). Depth to water table $(\mathrm{cm})$, conductivity $(\mu \mathrm{S} / \mathrm{cm})$, and $\mathrm{pH}$ were measured at each sampling site. Conductivity and $\mathrm{pH}$ were measured from as close as possible to the amoeba assemblage, typically by squeezing water from adjacent Sphagnum. Sphagnum moss samples were collected for species-level identification.

Preparation of peat samples for analyses of testate amoebae generally followed the method of Hendon and Charman (1997). Samples were boiled in $100 \mathrm{~mL}$ of distilled water for 10 minutes and then sieved through nested $355-\mu \mathrm{m}$ and $15-\mu \mathrm{m}$ filters. Material left in the $15-\mu \mathrm{m}$ sieve was put into a water solution and centrifuged at $3000 \mathrm{rpm}$ for five minutes. The supernatant was decanted and the remaining material stained with two drops of safranine-O dye and stored in glycerol. Using a light microscope at $400 \mathrm{x}$ magnification, testate amoebae were identified and counted until a total count of at least 150 was reached. Counts of the rotifer Habrotrocha angusticollis were included in the total amoeba counts, as it is commonly found in association with testate amoebae and has been included in calibration datasets from other regions (Charman, 1997; Charman and Warner, 1997; Booth, 2002). For each sample, the relative abundance of each taxon was calculated as a percentage of the total number of testate amoebae counted. Taxonomy was based solely on test morphology, and follows Charman et al. (2000) except as noted in Booth (2002) and Table 2.

\section{Peatland sediment coring}

An 89-cm long sediment core was collected approximately $30 \mathrm{~m}$ from the south-central edge of Robinson Peatland with a 10.2-cm diameter piston corer (Wright et al., 1984). The core was extruded in the field, wrapped in plastic film and aluminum foil, encased in plastic piping, and transported back to the laboratory for analysis. Approximately $2 \mathrm{~cm}^{3}$ of peat was collected from each centimeter for testate amoeba analysis. The upper 40 centimeters were analyzed continuously (every $\mathrm{cm}$ ), and every other centimeter was analyzed below $40 \mathrm{~cm}$. Testate amoebae were isolated from peat samples using the same procedures as modern collections.

\section{Analytical methods}

\section{Outlier removal}

To decrease the influence of anomalous samples, outlier analysis was performed on the dataset using PC-ORD (McCune \& Mefford, 1999) and Sørenson's distance measure, removing samples with species data more than two standard deviations from the mean. Three samples from Henderson Peatland A were also removed because of difficulties accurately measuring the water-table depth, which may have been related to the low porosity of a shallow clay/silt subsurface layer that extended from the upland into the edge of the peatland where those samples were collected. Testate amoeba taxa found in fewer than ten samples (Paraquadruella irregularis, Hyalosphenia elegans, Difflugia acuminate, Arcella gibbosa, Arcella hemisphaerica, Nebela lagenoformis, Nebela militaris, Lesquerusia sprialis) were removed from the data set prior to analysis. A total of 135 samples and 33 taxa remained (Table 2). 
follows Charman et al. (2000) with modifications of Booth (2002)

\begin{tabular}{|c|c|}
\hline Taxon & Abbreviation \\
\hline Arcella catinus Penard & arccat \\
\hline Arcella discoides Ehrenberg type & arcdis \\
\hline Arcella gibbosa Penard type & arcgib \\
\hline Arcella hemisphaerica Perty & archem \\
\hline Arcella vulgaris Ehrenberg & arcvul \\
\hline Assulina muscorum Greef & assmus \\
\hline Centropyxis aculeata (Ehrenberg) von Stein type & cenacu \\
\hline Centropyxis cassis (Wallich) Deflandre type & cencas \\
\hline Centropyxis platystoma (Penard) Deflandre type & cenpla \\
\hline Corythion-Trinema type & cortri \\
\hline Cryptodifflugia oviformis Penard & cryovi \\
\hline Cyclopyxis kahli Deflandre* & cyckah \\
\hline Cyphoderia ampulla Ehrenberg* & cypamp \\
\hline Difflugia acuminata Ehrenberg type & difacu \\
\hline Difflugia bacillifera Penard & difbac \\
\hline Difflugia globulosa Dujardin type & difglo \\
\hline Difflugia lucida Penard type & difluc \\
\hline Difflugia rubescens Penard & difrub \\
\hline Difflugia type A & difA \\
\hline Euglypha cristata Leidy* & eugcri \\
\hline Euglypha rotunda Wailes and Penard type & eugrot \\
\hline Euglypha strigosa (Ehrenberg) Leidy & eugstr \\
\hline Euglypha tuberculata Dujardin type & eugtub \\
\hline Habrotrocha angustichollis Murray** & habang \\
\hline Heleopara rosea/petricola Penard/Leidy & helros \\
\hline Heleopara sphagni (Leidy) Cash and Hopkinson & helsph \\
\hline Hyalosphenia elegans Leidy & hyaele \\
\hline Hyalosphenia papilio Leidy & hyapap \\
\hline $\begin{array}{l}\text { Lesqueresia spiralis/epistomium (Ehrenberg) } \\
\text { Bütschli/Penard }\end{array}$ & lesspi \\
\hline Nebela collaris (Ehrenberg) Leidy & nebcol \\
\hline Nebela lageniformis Penard & neblag \\
\hline Nebela militaris Penard & nebmil \\
\hline Nebela parvula Cash and Hopkinson & nebpar \\
\hline Nebela tubulosa Penard type & nebtub \\
\hline Nebela vitraea Penard type & nebvit \\
\hline Nebela wailesii Deflandre & nebwai \\
\hline $\begin{array}{l}\text { Paraquadrula irregularis (Deflandre) Archer } \\
\text { type*** }\end{array}$ & parirr \\
\hline Pseudodiffulgia fulva (Archer) Penard type & pseful \\
\hline Quadruella symmetrica (Wallich) Schulze & quasym \\
\hline Sphenoderia lenta Schlumberger & sphlen \\
\hline $\begin{array}{l}\text { Trigonopyxis arcula (Leidy) Penard type } \\
\text { (includes T. minuta) }\end{array}$ & triacu \\
\hline \multicolumn{2}{|c|}{$\begin{array}{l}{ }^{*} \text { taxonomy follows Ogden and Hedley (1980) } \\
\text { **taxonomy follows Warner and Chengalath (1988) } \\
{ }^{* * *} \text { taxonomy follows Meisterfeld (2000) } \\
\text { ***:Similar to Cyclopyxis arcelloides type (Booth, 2002), with } \\
\text { aperture diameter almost equal to diameter of test, a ragged and } \\
\text { uneven aperture margin, and the test usually strongly compressed. }\end{array}$} \\
\hline
\end{tabular}
except where noted by asterisks.

(Kruskal, 1964; Mather, 1976; McCune and Grace, 2002). NMS has advantages over other ordination methods because it does not make assumptions regarding underlying species distributions along compositional gradients (McCune and Grace, 2002; Clarke, 1993). We used Sørenson's distance measure in our analyses, along with the automated search feature of PC-ORD (McCune and Mefford, 1999) to identify the best solution and dimensionality. The automated search feature performed 40 runs with real data, each with a random starting configuration and consisting of solutions for 1 through 6 dimensions. Fifty runs with randomized data were then performed and statistics on the final stress at each dimensionality were accumulated. The best solution for each dimensionality was identified by comparing the final stress values.

\section{Developing an age-model for the sediment core}

An age model for the sediment core was developed using linear interpolation between an accelerator mass spectrometry (AMS) radiocarbon date at a depth of $88 \mathrm{~cm}$ and continuous analyses of ${ }^{210} \mathrm{~Pb}$ and ${ }^{137} \mathrm{Cs}$ on the upper $39 \mathrm{~cm}$. The University of Florida performed the analysis of ${ }^{210} \mathrm{~Pb}$ and ${ }^{137} \mathrm{Cs}$. The radiocarbon date was obtained from Sphagnum stems and leaves spanning a $1-\mathrm{cm}$ interval of peat. The radiocarbon age was calibrated to calendar-year age using CALIB 4.1 (Stuiver and Reimer, 1993; Stuiver et al. 1998).

Comparing temporal changes in testate amoebae with climate data

Fossil testate amoeba assemblages were positioned within the modern sample ordination, using the program PC-ORD and the NMS scores feature (McCune and Mefford, 2002). The procedure allows the fossil samples to be positioned in the original ordination space without altering the position of the original points. Fossil sample scores along each main axis of variation were compared with instrumental climate data, using climate divisions data obtained from the NOAA-CIRES Climate Diagnostics Center, Boulder, Colorado, USA, via the internet (http://www.cdc.noaa.gov). Climate division data are monthly averages of instrumental data from regions within states that are thought to be climatically uniform. We used climate division data 
from southeastern Idaho (Climate Division \#10) for our comparisons. Both the inferred NMS axis data and the climatic data were smoothed to decadal resolution to facilitate comparisons. The smoothing was done with a 10-year moving window, moved in 5-year time steps.

\section{$\uparrow \quad$ Results AND DisCUSSION}

Testate amoeba assemblages and controls on distribution

Testate amoebae of peatlands in the Rocky Mountain region have not been extensively studied. The most recent research dates to the late $1800 \mathrm{~s}$ (Leidy, 1879; Penard, 1891). This early work suggests that several taxa thought to be quite common in other regions were absent in the Rocky Mountains, including Hyalosphenia papilio, Nebela flabulellum, and Assulina seminulum (Penard, 1891). We did not observe Nebela flabulellum or Assulina seminulum in our Rocky Mountain samples. However, Hyalosphenia papilio occurred in some samples from floating peat mats in northwest Wyoming and adjacent Idaho, though it was absent from other sites. Our data indicate that several other taxa that are common in eastern North America and Europe, including Amphitrema flavum, Amphitrema wrightianum, Bulinularia indica, Heleopera sylvatica, Nebela carinata-marginata type, and Nebela griseola, are probably absent or rare in the Rocky Mountains (Booth and Zygmunt, 2004).

We selected a three-dimensional NMS solution for the ordination of the modern assemblage data from the Rocky Mountains, because additional dimensions resulted in only small reductions in stress. For the final ordination, the solution with the lowest final stress (final stress $=18.71, \mathrm{p}<0.05$ ) was used, and this solution represented $80 \%$ of the variation in the dataset (Table 3). Axis 2 was strongly correlated with most of the environmental variables we measured, including water-table depth, percent moisture, $\mathrm{pH}$, and conductivity (Figure 2, Table 3). Taxa with high scores on this axis, including Difflugia globulosa type, Arcella vulgaris type, and Nebela tubulosa, tend to be associated with wet habitats, high pH, and low conductivity (Figure
2). Taxa with low scores on this axis, including Trigonopyxis arcula, Assulina muscorum, and Nebela parvula, are generally associated with dry habitats, low pH, and high conductivity (Figure 2). The patterns along axis 2 are consistent with results from other regions, where substrate moisture and aspects of water chemsitry have been identified as the dominant controls of taxa distribution patterns (e.g., Charman and Warner, 1992, 1997; Charman, 1997; Woodland et al., 1998; Mitchell et al., 1999; Booth 2001, 2002). The ecology of individual taxa with respect to moisture conditions is also similar to other regions (Booth and Zygmunt, 2004).
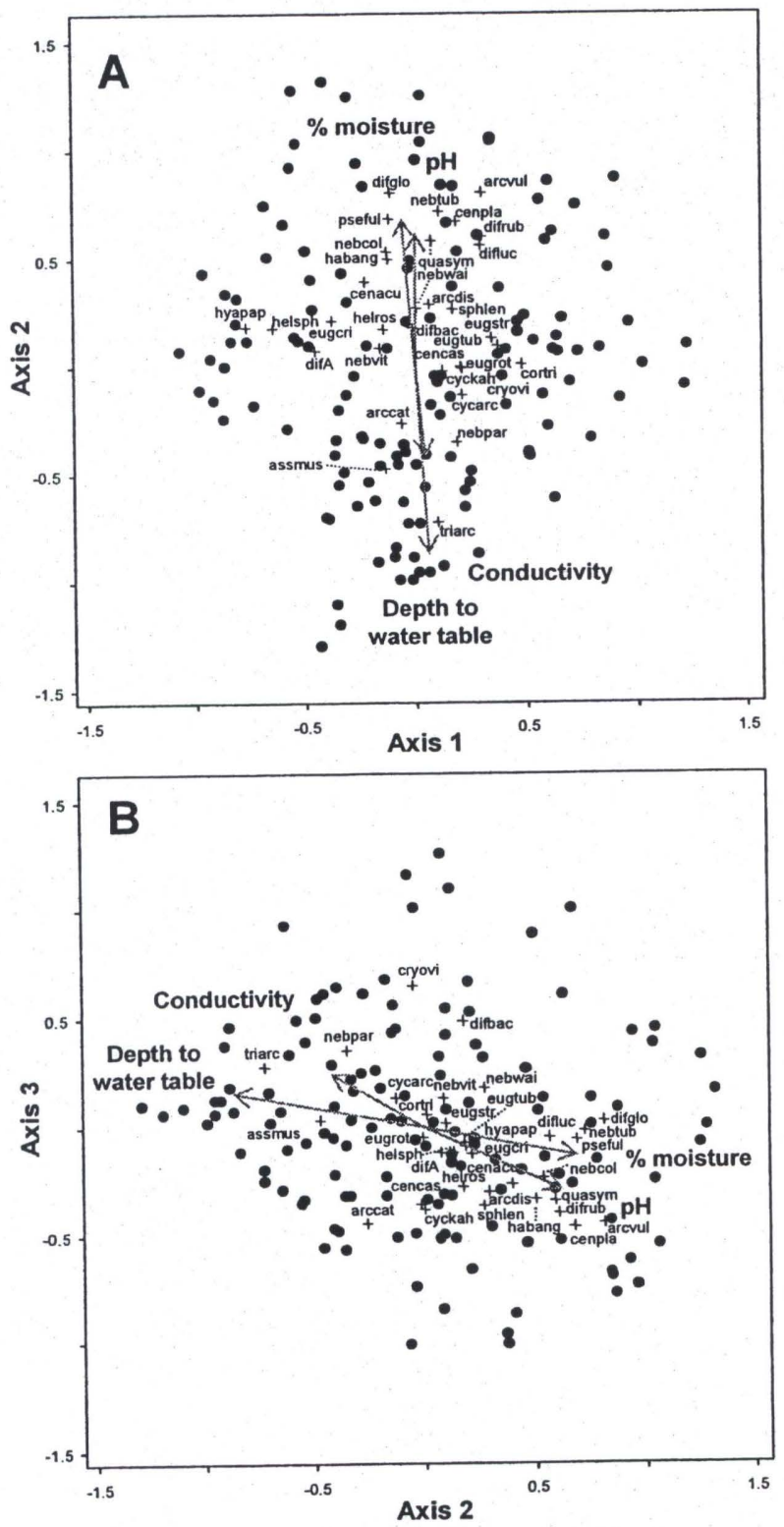

Figure 2. Three-dimensional NMS ordination of modern testate amoeba samples collected in the Rocky Mountains, with sample and species scores for axes 1 and 2 shown in A and scores for axis 2 and 3 shown in B. Abbreviations for species are shown in Table 2. Biplot shows the relative strength of axis-environment correlations, for variables with strong correlations $\left(r^{2}>0.2\right)$. Axisenvironment correlations and percent variance explained are shown in Table 3 . 
The other two NMS axes were not correlated with any environmental variables we measured. However, each of these axes explains about $20 \%$ of the variability in the dataset (Table 3 ), suggesting that they represent important patterns of variability and that other controls on distribution patterns may exist in the Rocky Mountains. Taxa with high scores along axis 1 include CorythionTrinema type and Cryptodifflugia oviformis, and taxa with low scores include Hyalosphenia papilio and Heleopera sphagni. Taxa with high scores along axis 3 include Centropyxis platystoma type and Arcella catinus, and taxa with low scores along this axis include Cryptodifflugia oviformis and Difflugia bacilifera.

\section{Past variability in testate amoebae and environment at Robinson Peatland}

\section{Age model}

Analysis of ${ }^{210} \mathrm{~Pb}$ and ${ }^{137} \mathrm{Cs}$ revealed excess ${ }^{210} \mathrm{~Pb}$ present to a depth of $38 \mathrm{~cm}$ in the peatland sediment core, and a prominent spike in ${ }^{137} \mathrm{Cs}$ occurred at a depth of about $23 \mathrm{~cm}$ (Figure 3). The ${ }^{137} \mathrm{Cs}$ spike is attributable to nuclear weapons testing in the 1960s. Rapid accumulation or mixing occurred between 12 and $19 \mathrm{~cm}$ (Figure 3), and the ${ }^{137} \mathrm{Cs}$ peak at 1963 A.D. suggested separate sedimentation rates should be applied above and below this interval. Several models were explored, including constant initial concentration (CIC), constant rate of supply (CRS), and constant flux:constant sedimentation rate (CF:CS) models. A CF:CS model provided the most reliable results (J. Cable, personal communication), and indicates sedimentation rates of $2.97 \mathrm{~mm} / \mathrm{yr}$ in the upper $12 \mathrm{~cm}$, and $2.80 \mathrm{~mm} / \mathrm{yr}$ from 19 to $38 \mathrm{~cm}$. Linear interpolation from the basal radiocarbon date suggests an average sedimentation rate of $2.09 \mathrm{~mm} / \mathrm{yr}$ below 38-cm depth.

\section{Testate amoeba stratigraphy}

Depth-to-water-table is an important control on testate amoeba distribution in the Rocky Mountains (Figure 2) and elsewhere (e.g., Woodland et al., 1998; Booth, 2002). Therefore, we expected little temporal variability in the relative abundance of testate amoebae at Robinson Peatland because the floating mat should rise and fall with fluctuations in basin water levels, and hence depth-to-water-table should remain relatively constant. However, the abundance of several taxa varied substantially in the core (Figure 4). Taxa that showed particularly large vertical changes in abundance included Hyalosphenia papilio and Pseudodifflugia fulva type, which fluctuated by more than $50 \%$ in their relative abundance within the core (Figure 4). Relative abundance of other taxa also varied considerably, particularly taxa with relatively low NMS axis 1 scores in the modern dataset (e.g., Hyalosphenia papilio, Heleopera sphagni, Centropyxis aculeata type). The positioning of fossil samples within the ordination of modern samples indicates a good deal of overlap between modern and fossil samples, although the range of variability is less within the fossil dataset (Figure 5).

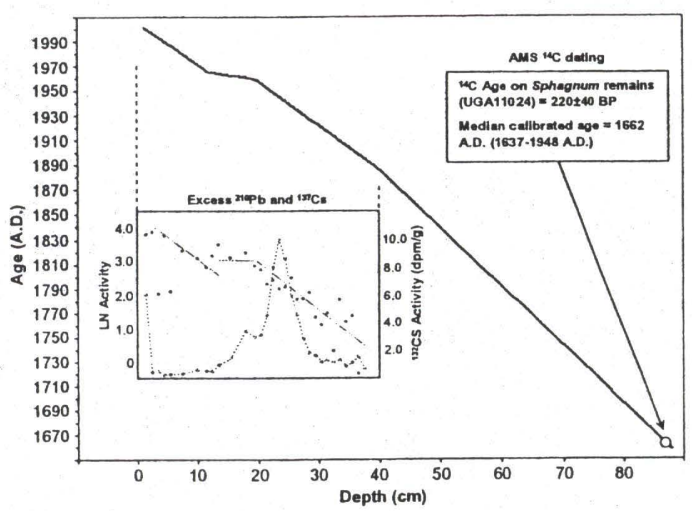

Figure 3. Age-depth model for the Robinson peat core and vertical distribution of excess ${ }^{210} \mathrm{~Pb}$ and ${ }^{137} \mathrm{Cs}$. $\mathrm{N}$ ote the distinct peak in ${ }^{137} \mathrm{Cs}$ at about $23-\mathrm{cm}$ depth and the apparent event layer between 12 and $19-\mathrm{cm}$ depth, which may have been caused by mixing or rapid deposition. Application of a constant flux:constant sedimentation rate model separately to the periods before and after the event layer gave the most consistent results, suggesting sedimentation rates in the upper $12 \mathrm{~cm}$ were about $2.97 \mathrm{~mm} / \mathrm{yr}$ and about $2.8 \mathrm{~mm} / \mathrm{yr}$ from 38 to $19 \mathrm{~cm}$ depth.

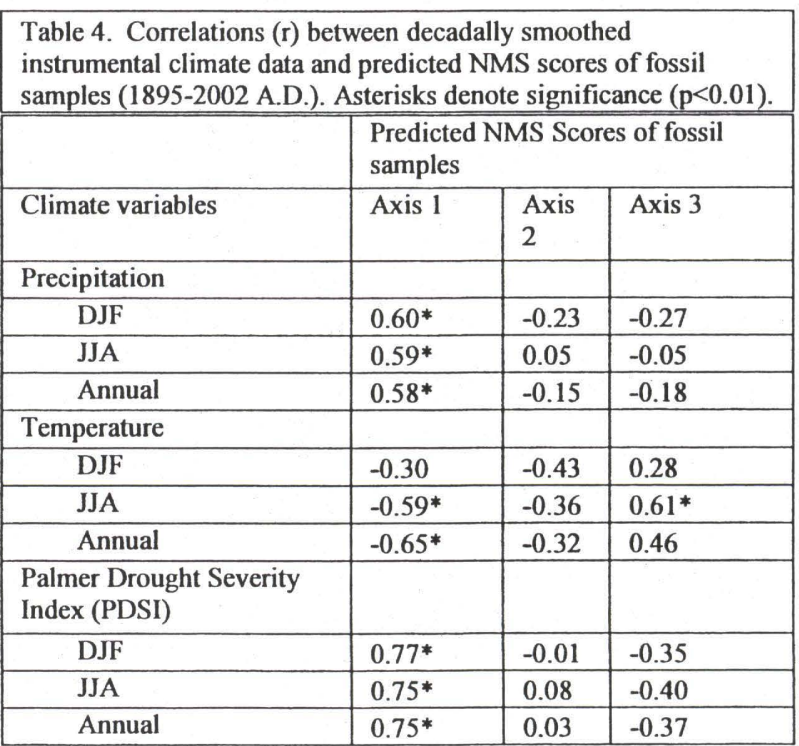




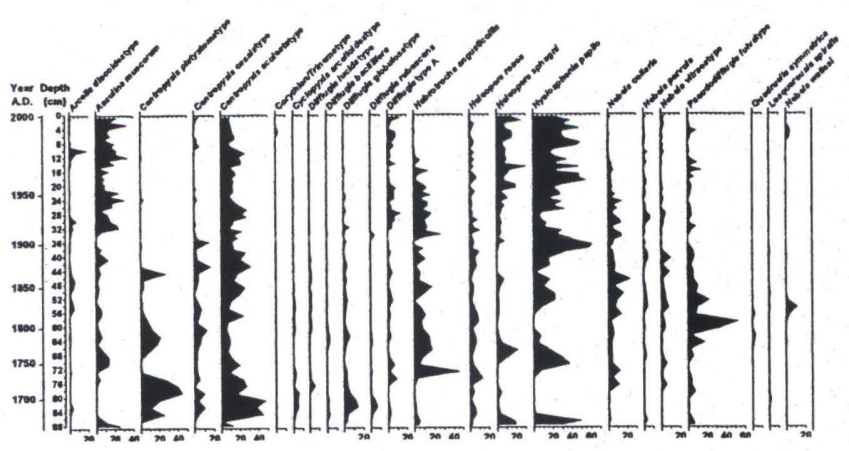

Figure 4. Vertical changes in the relative abundance of testate amoebae in the Robinson peatland sediment core.

\section{A paleoclimate record from a floating peat mat?}

We expected that testate amoebae from a floating peat mat would be relatively insensitive to climate variability, because of the stability of water-table depth on the floating mat. However, comparison between instrumental climatic data for the last century and temporal variability in testate amoebae suggests that climatic variation influenced testate amoeba populations at decadal timescales (Table 4). Significant correlations exist between variability along NMS axis 1 and temperature, precipitation, and a commonly used measure of drought, the Palmer Drought Severity Index (PDSI) (Table 4, Figure 6). A correlation between NMS axis 3 scores and temperature also exists (Table 4, Figure 6). However, this correlation appears to be related to the long-term warming trend in temperature during the $20^{\text {th }}$ century, and the long-term trend in the testate amoeba data could conceivably be due to some other long-term process. Temporal variability in testate amoebae along NMS Axis 2 did not show any significant relationships with climate data, even though variability along this axis was correlated with several environmental variables in the modern dataset (Figure 2).

Why is variability along NMS axis 1 correlated with drought during the past century? We hypothesize that, although depth-to-water-table and peat saturation remain constant on floating mats, moisture conditions at and near the peat surface (i.e., the uppermost portions of living Sphagnum) are affected by temperature, evaporation, and precipitation. Fluctuations in NMS axis 1 scores appear to be primarily related to changes in the relative abundance of Hyalosphenia papilio and Heleopera sphagni. These two taxa increase during drier time periods and decrease during wetter time periods. It is probably significant that these two taxa contain symbiotic zoochlorellae, and are typically concentrated on upper portions of the Sphagnum stem (e.g., Heal; 1962; Meisterfeld, 1977; Booth 2002). Moisture content and other properties of the distal portions of Sphagnum plants are likely sensitive to seasonal, annual, and decadal variations in climate, and so these microenvironmental variations could drive variations in local testate amoeba populations. Distal Sphagnum microenvironments at Robinson Peatland are presumably more favorable for Hyalosphenia papilio and Heleopera sphagni during dry periods. Although the mechanisms of this relationship remain to be worked out, the strong correlation between the instrumental record and the testate-amoeba record at Robinson Peatland indicates that paleoclimate inferences can be made from floating peat mats in the region.
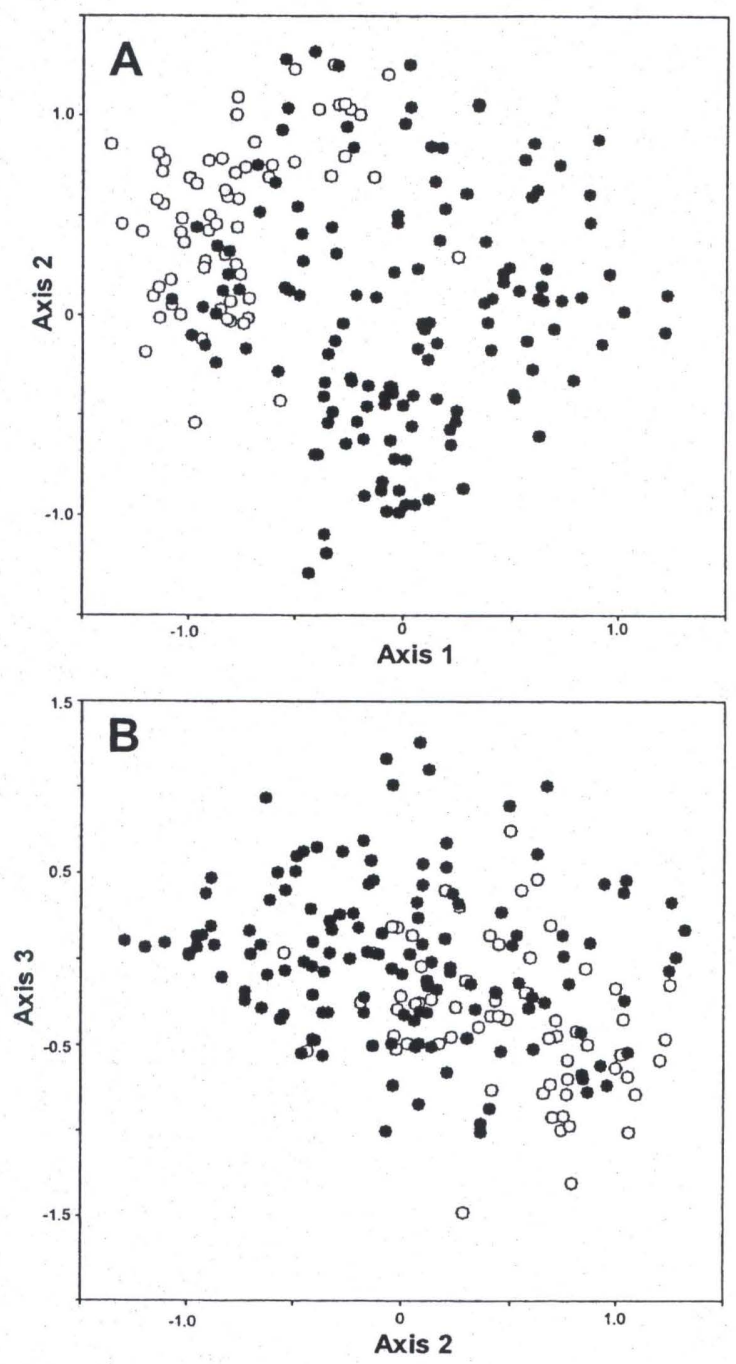

Figure 5. NMS ordination of the modern calibration dataset (closed circles) with predicted scores for fossil samples from Robinson peatland (open circles) for A) axes 1 and 2 and B) axes 2 and 3 . 


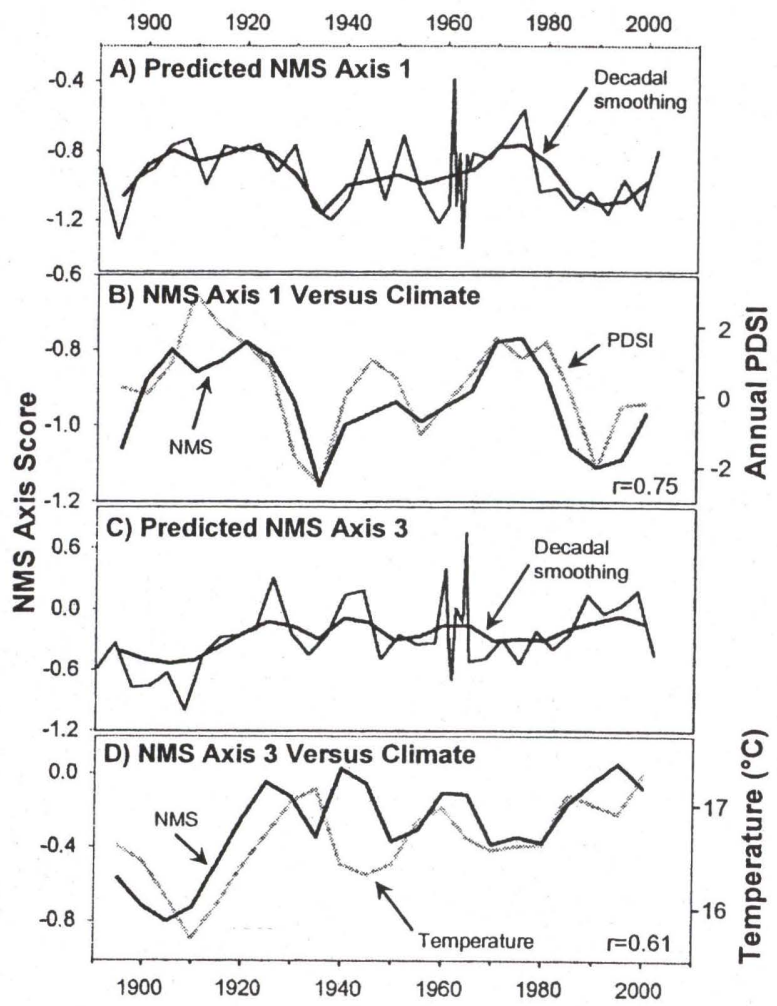

Figure 6. Comparison of the instrumental climatic record with the testate amoeba record of Robinson peatland, for statistically significant correlations (see Table 4). A) Temporal changes in predicted NMS axis 1 scores of testate amoeba samples showing raw data and decadal smoothing. B) Comparison of decadally smoothed NMS axis 1 scores and Palmer Drought Severity Index (PDSI). C) Temporal changes in predicted NMS axis 3 scores of testate amoeba samples showing raw data and decadal smoothing. D) Comparison of decadally smoothed NMS axis 3 scores and temperature.

\section{CONCLUSIONS}

Testate amoebae are an underutilized paleoenvironmental proxy, and have great potential for reconstructing past climate variability from peatland sediments of the Rocky Mountain region. As in other studied regions, the dominant controls on species distribution patterns within peatlands of the Rocky Mountains are substrate moisture and water chemistry. A testate amoeba record from a floating peat mat in Yellowstone National Park is correlated with instrumental records of drought during the past century, suggesting strong potential for drought reconstructions at decadal timescales from floating mats in the region, and possibly elsewhere. Assuming suitable sites can be located, testate amoeba-based climatic reconstructions have the potential to extend over longer periods than tree-ring records, and are higher in resolution than those obtained by plant macrofossils and pollen. Testate amoebae can be used to provide information on past peatland hydrology, which would be particularly useful in the Rocky Mountain region, where water resources are critical for land management.

\section{ACKNOWLEDGEMENTS}

Funding for this project came from a University of Wyoming - National Parks Service Grant. Modern testate amoeba studies were also funded by grants to J.R. Zygmunt from the Wyoming NASA Space Grant Consortium (NASA Grant \#NGT-40102) and Wyoming NASA EPSCoR (NASA Grant \#NCC5-578). We thank Richard Andrus for providing Sphagnum moss identifications. We also thank the many people who helped with field work and/or provided helpful discussions, including Denise Culver, Judith Harpel, Ron Hartman, Bonnie Heidel, Scott Laursen, and Jennifer Whipple. We thank Jaye Cable for analyzing and interpreting the ${ }^{210} \mathrm{~Pb}$ and ${ }^{137} \mathrm{Cs}$ data.

\section{Literature Cited}

Anderson, D.E. 1998. A reconstruction of Holocene climatic changes from peat-bogs in northwest Scotland. Boreas 27, 208-224.

Barber, K.E. 1993. Peatlands as scientific archives of past biodiversity. Biodiversity and Conservation 2, 474-489.

Barber, K.E., Maddy, D., Rose, N., Stevenson, A.C., Stoneman, R., and Thompson, R. 2000. Replicated proxy-climate signals over the last $2000 \mathrm{yr}$ from two distant UK peat bogs: new evidence for regional palaeoclimate teleconnections. Quaternary Science Reviews 19, 481-487.

Barber, K.E., Chambers, F.M., and Maddy, D.M. 2003. Holocene palaeoclimates from peat stratigraphy: macrofossil proxy climate records from three oceanic raised bogs in England and Ireland. Quaternary Science Reviews 22, 521-539.

Blackford, J.J. 1993: Peat bogs as sources of proxy climatic data: past approaches and future research. In Chambers, F.M. editor, Climate change and human impact on the landscape, London: Champman and Hall, 49-56. 
Booth, R.K. 2001. Ecology of testate amoebae (Protozoa) in two Lake Superior coastal wetlands: implications for paleoecology and environmental monitoring. Wetlands 21, 564-576.

Booth, R.K. 2002. Testate amoebae as paleoindicators of surface-moisture changes on Michigan peatlands: modern ecology and hydrological calibration. Journal of Paleolimnology 28, 329-348.

Booth, R.K., and Jackson, S.T. 2003. A highresolution record of late Holocene moisture variability from a Michigan raised bog. The Holocene 15, 863-876.

Booth, R.K., and Zygmunt, J.R. 2004. Biogeography and comparative ecology of testate amoebae inhabiting Sphagnum-dominated peatlands in the Great Lakes and Rocky Mountain regions of North America. Diversity and Distributions, in review.

Booth, R.K., Gray, C.E.D., and Jackson, S.T. 2004. Paleoecology and high-resolution paleohydrology of a kettle peatland in Upper Michigan. Quaternary Research 61, 1-13.

Carsey, K., Coles, J., Decker, K., and Fenwick, R. 1999. Identification and evaluation of wetlands of statewide significance in Colorado. Colorado Natural Areas Program Report.

Chambers, F.M., Barber, K.E., Maddy, D., and Brew, J. 1997. A 5500-year proxy-climate and vegetation record from a blanket mire at Talla Moss, Borders, Scotland. The Holocene 7, 391-399.

Charman, D.J., and Hendon, D. 2000. Long-term changes in soil water tables over the past 4500 years: relationships with climate and North Atlantic atmospheric circulation and sea surface temperature. Climatic Change 47, 45-59.

Charman, D.J., and Warner, B.G. 1992. Relationship between testate amoebae (Protozoa: Rhizopoda) and microenvironmental parameters on a forested peatland in northeastern Ontario. Canadian Journal of Zoology 70, 2474-2482.
Charman, D.J., and Warner, B.G. 1997. The ecology of testate amoebae (Protozoa: Rhizopoda) in oceanic peatlands in Newfoundland, Canada: modeling hydrological relationships for palaeoenvironmental reconstruction. Ecoscience 4, 555-562.

Charman, D.J., Hendon, D. and Woodland, W.A. 2000. The identification of testate amoebae (Protozoa: Rhizopoda) in peats. Quaternary Research Association Technical Guide no. 9, London, 147 pp.

Charman, D.J., Karofeld, E., Brown, A.D., and Hendon, D. 2004. Testing the relationship between Holocene peatland palaeoclimate reconstructions and instrumental data at two European sites. Quaternary Science Reviews 23: 137-143.

Charman, D.J. 1997. Modelling hydrological relationships of testate amoebae (Protozoa: Rhizopoda) on New Zealand peatlands. Journal of the Royal Society of New Zealand 27, 465-483.

Charman, D.J. 2002. Peatlands and environmental change. John Wiley and Sons, West Sussex.

Charman, D.J. 2001. Biostratigraphic and palaeoenvironmental applications of testate amoebae. Quaternary Science Reveiws 20, 1753-1764.

Clarke, K.R. 1993. Non-parametric multivariate analyses of changes in community structure. Australian Journal of Ecology 18, 117-143.

Heal O.W. 1962. The abundance and microdistribution of testate amoebae (Rhizopoda: Testacea) in Sphagnum. Oikos 13: 35-47.

Hendon, D., and Charman, D.J. 1997. The preparation of testate amoebae (Protozoa: Rhizopoda) samples from peat. The Holocene 7, 199-205.

Hendon, D., and Charman, D.J. 2004. Highresolution peatland water-table changes for the past 200 years: The influence of climate and implications for management. The Holocene 14: 125-134 
Hendon, D., Charman D.J., and Kent, M. 2001. Palaeohydrological records derived from testate amoebae analysis from peatlands in northern England: within-site variability, between-site comparability and palaeoclimatic implications. The Holocene $11,127-148$.

Hughes, P.D.M., Mauquoy, D., Barber, K.E., and Langdon, P.G. 2000. Mire-development pathways and palaeoclimate records from a full Holocene peat archive at Walton Moss, Cumbria, England. The Holocene 10, 465479.

Kruskal, J.B. 1964. Nonmetric multidimensional scaling: a numerical method. Psychometrika 29, 115-129.

Langdon, P.G., Barber, K.E., and Hughes, P.D.M. 2003. A 7500-year peat-based palaeoclimatic reconstruction and evidence for an 1100-year cyclicity in bog surface wetness from Temple Hill Moss, Pentland Hills, southeast Scotland. Quaternary Science Reviews 22, 259-274.

Leidy, J. 1879. Fresh-water rhizopods of North America. Report of the United States Geological Survey of the territories, Volume XII, Washington, D.C., Government Printing Office, 324 pages.

Mather, P.M. 1976. Computational methods of multivariate analysis in physical geography. J. Wiley and Sons, London. 532 pp.

McCune, B. and Grace, J.B. 2002. Analysis of ecological communities. MjM Software, Gleneden Beach, Oregon, USA. 300 pp.

McCune, B. and Mefford, M.J. 1999. PC-ORD. Multivariate analyses of ecological data. Version 4.0. MjM Software, Gleneden Beach, Oregon, USA.

Meisterfeld, R. 1977. Die horizontale und vertikale Verteilung der Testaceen (Rhizopoda, Testacea in Sphagnum. Archiv für Hydrobiologie, 79, 319-356.

Mitchell, E.A.D. and Gilbert, D. 2004. Vertical micro-distribution and response to nitrogen deposition of testate amoebae in Sphagnum. Journal of Eukaryotic Microbiology 51, 480490.
Mitchell, E.A.D., Buttler, A.J., Warner, B.G., and Gobat, J. -M. 1999. Ecology of testate amoebae (Protozoa: Rhizopoda) in Sphagnum peatlands in the Jura mountains, Switzerland and France. Ecoscience 6, 565576.

Penard, E. 1891. Rocky Mountain Rhizopods. American Naturalist 25, 1070-1083.

Stuiver, M., and Reimer, P.J. 1993. Extended ${ }^{14} \mathrm{C}$ database and revised CALIB 4.1 14C age calibration program. Radiocarbon 35, 215230 .

Stuiver, M., Reimer, P.J., Bard, E., Beck, J.W., Burr, G.S., Hughen, K.A., Kromer, B., McCormac, G., Van Der Plicht, J., and Spurk, M. 1998. INTCAL98 radiocarbon age calibration, 24,000-0 cal BP. Radiocarbon 40, 1041-1083.

Warner, B.G., and Charman, D.J. (1994) Holocene changes on a peatland in northwestern Ontario interpreted from testate amoebae (Protozoa) analysis. Boreas, 23, 271-279.

Warner, B.G. and Chengalath, R. 1988. Holocene fossil Habrotrocha angusticollis (Bdelloidea: Rotifera) in North America. Journal of Paleolimnology 1, 141-147.

Warner, B.G. 1987. Abundance and diversity of testate amoebae (Rhizopoda, Testacea) in Sphagnum peatlands in southwestern Ontario, Canada. Archiv für Protistenkunde 133, 173-189.

Windell, J.T., Willard, B.E., Cooper, D. J., Foster, S.Q., Knud-Hansen, C.F., Rink, L.P., and Kiladis, G.N. 1986. An ecological characterization of Rocky Mountain montane and subalpine wetlands. U.S. Fish and Wildlife Service Biological Report 86(11), $298 \mathrm{pp}$.

Wilmhurst, J.M., Wiser, S.K., and Charman, D.J. 2003. Reconstructing Holocene water tables in New Zealand using testate amoebae: differential preservation of tests and implications for the use of transfer functions. The Holocene 13, 61-72. 
Woodland, W.A., Charman, D.J., and Sims, P.C. 1998. Quantitative estimates of water tables and soil moisture in Holocene peatlands from testate amoebae. The Holocene 8, 261-273.

Wright, H.E., Jr., Mann, D.H., and Glaser, P.H. 1984.

Piston corers for peat and lake sediments. Ecology 65, 657-659. 